\title{
Mapping the low enthalpy geothermal potential of shallow Quaternary aquifers in Finland
}

Teppo Arola ${ }^{1 *}$, Lari Eskola², Jukka Hellen ${ }^{3}$ and Kirsti Korkka-Niemi ${ }^{4}$

\author{
* Correspondence: \\ teppo_arola@golder.fi \\ ${ }^{1}$ Golder Associates Oy, Apilakatu \\ 13B, Turku FI-20540, Finland \\ Full list of author information is \\ available at the end of the article
}

\begin{abstract}
Background: EU member states have concluded an agreement that renewable energy will cover $20 \%$ of the total energy production by 2020 . To achieve this target, it is essential to investigate all possibilities for renewable energy production. We investigated whether groundwater could provide a shallow geothermal energy resource, and to what extent it could meet the demands for heating buildings in Finland. Our research focused on classified aquifers, namely, groundwater areas that are zoned for urban or industrial use.

Methods: The heating potential of Finnish aquifers was estimated based on the flux, temperature and heat capacity of groundwater and the efficiency of heat pumps. The design power of residential buildings was then simulated. Finally, the design power was divided by the groundwater power to determine the ability of groundwater to heat buildings.

Results: Approximately 56,500 ha of Finnish aquifers are zoned for urban or industrial land use. These aquifers contain 40 to $45 \mathrm{MW}$ of power. In total, 55 to $60 \mathrm{MW}$ of the heat load could be utilised with heat pumps, meaning that $25 \%$ to $40 \%$ of annually constructed residential buildings could be heated utilising groundwater in Finland.

Conclusions: There are several hundred sites in Finland where groundwater could be used for energy utilisation, and groundwater could thus be a significant source of local renewable energy. However, because of geological and geographical factors, groundwater cannot be considered as a nationwide energy source. Future research should define the area-specific limiting factors for groundwater energy use.
\end{abstract}

Keywords: Aquifer; Open-loop system; Heat pump; Design power; Energy potential; Finland

\section{Background}

EU member states are committed to promoting the use of renewable energy sources (RES) by accepting the EU directive 2009-28-EN. In Europe, the share of RES systems should reach $20 \%$ by the year 2020 . One form of RES is groundwater, which can be exploited to supply the heating and/or cooling demands of residential households or industries. Hence, groundwater is not only a source of individual or municipal drinking water but also a resource for renewable energy production. The low enthalpy energy in shallow aquifers, typically below $100 \mathrm{~m}$ in depth, indicates an energy resource in which the temperature is below $30^{\circ} \mathrm{C}$ (Allen and Milenic 2003; Banks 2010). This geothermal energy is mostly derived from solar radiation (Fetter 1994), as only a minor proportion 
of stored energy in shallow aquifers originates from the Earth's internal heat or from heat produced by plate tectonics (Banks 2010). Several studies have demonstrated that shallow aquifers under cities can be a significant low enthalpy energy source (Allen et al. 2003; Kerl et al. 2012; Zhu et al. 2010). The Netherlands is an example of a country with widespread groundwater energy utilisation, where over 3,000 heat pumps were in use, and over 200 million $\mathrm{m}^{3}$ of water was pumped for energy utilisation in 2010 (Statistics Netherlands 2012). Two good examples of groundwater utilisation in Nordic countries are Gardermoen airport in Oslo, Norway, and Arlanda airport in Stockholm, Sweden. Both airports are located on a glaciofluvial gravel and sand deposit: Gardermoen is operating with a maximum groundwater capacity of 20 to $25 \mathrm{~m}^{3} / \mathrm{h}$ (Eggen and Vangsnes 2005), and Arlanda with a capacity of $720 \mathrm{~m}^{3} / \mathrm{h}$ (Persson 2007). A demonstration heating plant, with a heat pump capacity of $72 \mathrm{~m}^{3} / \mathrm{h}$ groundwater, was also built in Forssa, southern Finland, in 1984 to 1985 (Iihola et al. 1988).

The technique for groundwater energy utilisation is designated as an open system or open-loop system. In an open-loop system, groundwater is circulated between two or more groundwater wells, and energy is extracted from the flowing water by a heat transfer system (Bonte et al. 2011; Haehlein et al. 2010). If the heating energy is produced by a heat pump, the term groundwater heat pump (GWHP) system is also used (Haehlein et al. 2010). Most typically, groundwater is pumped from springs, wells, boreholes or flooded mines to GWHP systems. The principle of a double-well GWHP system is illustrated in Figure 1.

GWHP systems require a particular environment to work properly. The main requirements are soil and rock that possess a relatively high water conductivity of $10^{-5}$ to $10^{-1} \mathrm{~m} / \mathrm{s}$ and a suitable chemical composition of groundwater (Sanner 2001). A high hydraulic conductivity of the soil or rock allows sustainable groundwater circulation (Kalf and Woolley 2005; Zhou 2009), so that the abstraction and re-injection of groundwater has a minimal local effect on groundwater storage, whilst suitable chemical properties of the groundwater, i.e. relatively low concentrations of iron (Fe), manganese $(\mathrm{Mn})$,

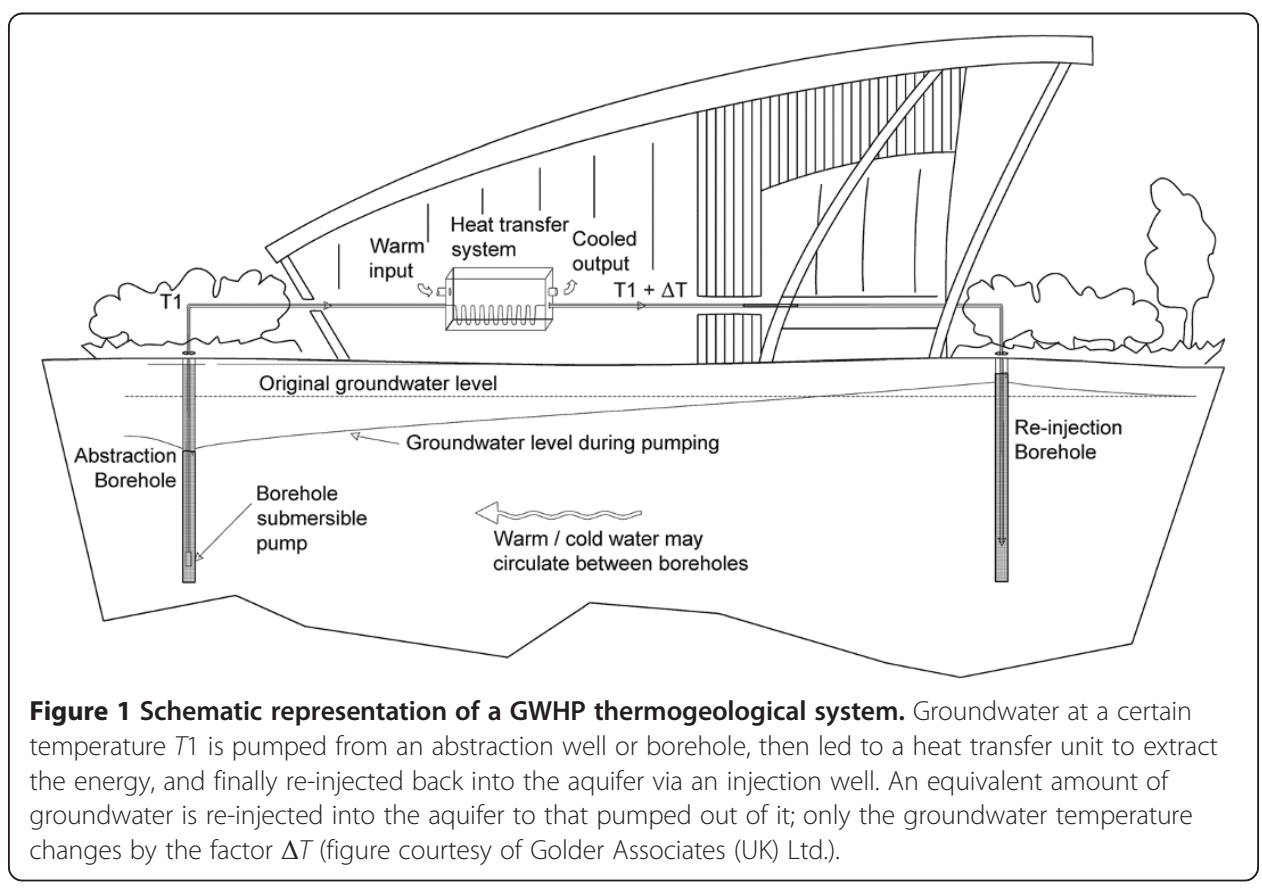


carbon dioxide $\left(\mathrm{CO}_{2}\right)$ and chloride $\left(\mathrm{Cl}^{-}\right)$, are essential to avoid clogging and corrosion of the GWHP system (Lindblad-Påsse 1986; Sanner 2001). An inadequate design or unfavourable environmental conditions may allow excessive groundwater flow from the injection well to the abstraction well, and hence may reduce the efficiency of the GWHP system. Especially in the Nordic region, the implementation of groundwater as a source of heating energy can also fail due to the low natural temperature of groundwater.

Finland is one of the world's leading users of RES. In 2010, RES supplied 30.2\% of the final consumption of energy (Statistics Finland 2012), whilst the target share of RES in the gross final energy consumption of Finland in 2020 has been set at 38\% by EU directive 2009-28-EN. The objective of the National Energy and Climate Strategy is to increase the use of renewable energy sources and their share of total energy consumption (Ministry of Employment and the Economy 2008). In 2011, approximately 8\% of the energy for heating buildings, 3 to 4 TWh, was produced by air, air-water and ground source heat pumps (Statistics Finland 2012), but it is estimated that the use of heat pump energy should double from current levels by the end of 2020 (Ministry of Employment and the Economy 2010). Ground source heat pumps accounted for approximately $40 \%$ of the total heat production by heat pumps in 2011 (Statistics Finland 2012). Groundwater use for energy production in Finland is controlled by the Water Act and the Environmental Protection Act. However, there are no national regulations concerning the temperature threshold limits, unlike, for example, in Austria and Germany, where a temperature difference of $6 \mathrm{~K}$ has been set as the groundwater threshold limit for open-loop systems (Haehlein et al. 2010). If the benefits of groundwater utilisation are greater than the disadvantages, the application for a permit for groundwater utilisation will be approved according to Finnish legislation (Water Act 2011).

In order to achieve the RES targets by the year 2020, it is necessary to recognise all potential renewable energy resources in EU member states. Despite the favourable legislation, which does not pose significant obstacles to groundwater pumping, as well as the GWHP experiment in the 1980s (Iihola et al. 1988), GWHP systems are not widely recognised as an option for RES in Finland. In this study, we explored how significant a heating energy resource groundwater could be in Finland. We measured three parameters that describe the heating potential of aquifers: (1) the potential heat power capacity that Finnish aquifers under urban or industrial land use can produce, (2) the amount of heating power that can be delivered to heat distribution systems of buildings from such aquifers by utilising heat pumps and (3) the surface area $\left(\mathrm{m}^{2}\right)$ of detached houses and apartment buildings that could be heated using groundwater heating power.

\section{Methods}

\section{Thermogeological environment in Finland}

The Precambrian bedrock of Finland is covered by a continuous, thin layer of glacial and postglacial sediment deposited during the Weichselian glacial stage and the Holocene, varying in thickness from a few metres to some tens of metres (Lahermo et al. 1990; Lunkka et al. 2004; Saarnisto and Salonen 1995). The lowermost sediment units consist of till. However, the main aquifers in Finland are found in glaciofluvial sand and gravel deposits, i.e. eskers or ice-marginal end moraine complexes, the most extensive of which are the Salpausselkä end moraines. Aquifers are normally unconfined, but semi-confined or 
confined aquifers also exist, because clay deposits in glaciolacustrine lakes or the Baltic Sea often cover the surface of the terrain in southern parts of Finland. The hydraulic conductivity of Finnish glaciofluvial sand/gravel aquifers is high, normally between $10^{-5}$ and $10^{-2} \mathrm{~m} / \mathrm{s}$ (Salonen et al. 2014; Salonen et al. 2001), which allows a relatively high groundwater abstraction and injection rate. Finland has 5,957 categorised aquifers, referred to as groundwater areas, with hydrogeological information on these being stored in the publically accessible Hertta Database (Britschgi et al. 2009; The Hertta Database 2012). The estimated natural recharge of Finnish groundwater areas is approximately 5.4 million $\mathrm{m}^{3}$ of water per day (The Hertta Database 2012). Although in some cases, an entire aquifer is not recognised as a groundwater area, it may include local groundwater supply wells that can be classified as point-sized groundwater areas (Britschgi et al. 2009). Areal information on point-sized aquifers is provided in a spot-like form, with an area of $0 \mathrm{~m}^{2}$, in The Hertta Database (2012). The data used in this investigation also include point-sized groundwater areas.

The reported mean groundwater temperature in Finland varies from $3.5^{\circ} \mathrm{C}$ to $6.6^{\circ} \mathrm{C}$ (Mälkki and Soveri 1986; Oikari 1981), being higher in southern Finland and lower in northern Finland. Hence, this paper considers a low enthalpy groundwater resource with a temperature of under $10^{\circ} \mathrm{C}$. In general, groundwater quality is suitable for GWHP systems in Finnish aquifers, although the chemical composition of groundwater varies between different parts of the country. High Fe, $\mathrm{Mn}$ and/or $\mathrm{Cl}^{-}$concentrations exist in confined aquifers of coastal areas, where clay deposits overlay sand or gravel units (Korkka-Niemi 2001; Lahermo et al. 1990).

\section{Novel groundwater energy database: combining aquifer and land use data}

Each of the classified aquifers with its land use data was analysed, totalling 5,957 groundwater areas. Groundwater data were collected from The Hertta Database (2012), and land use data from the Corine 2006 Database (2006). Both databases are managed by the Finnish Environment Institute. The 15 Centres for Economic Development, Transport and the Environment (ELY) are responsible for the control, protection and monitoring of groundwater areas and hence deliver hydrological information to the Hertta Database. The land use categories in The Corine 2006 Database (2006) were created according town planning information, which allowed us to divide the land use in the aquifer areas into urban or industrial. A novel groundwater energy database, combining the groundwater area and land use information, was created using the ArcGis 10 software. The data from Hertta and Corine databases was supplemented with 15 personal enquiries and interviews, including one person from each ELY Centre, during the process. If the Hertta Database did not have a recharge value for a particular aquifer, it was estimated based on the interviews or on pumping information from water intake plants. Only point-sized groundwater areas with an estimated yield of $100 \mathrm{~m}^{3} /$ day or more, which were zoned for urban and/or industrial land use, were selected for our study. These areas were manually added to the groundwater energy database.

\section{Groundwater flux estimation}

To document the amount of groundwater available for energy production, we estimated the groundwater flux of each aquifer, namely, the groundwater area. As the groundwater 
abstraction and injection rates are equal during energy utilisation, the natural recharge value is used for the value of the groundwater flux. Aquifers are often zoned for partly urban or industrial land, and partly outside of these land use forms, especially when the aquifer area is large. To estimate the groundwater flux of a portion of an aquifer, the aquifer's proportional land use ratio is calculated (see Figure 2). For example, the total size of the Kylmäkoski aquifer in the municipality of Akaa is $84.34 \mathrm{ha}$, and the total recharge is $348 \mathrm{~m}^{3}$ /day (The Hertta Database 2012). The area under urban land use is 15.48 ha (18.36\%) of the Kylmäkoski aquifer (The Corine Database 2006). In this study, the estimated groundwater flux of $63.89 \mathrm{~m}^{3} /$ day $\left(18.36 \% \times 348 \mathrm{~m}^{3} /\right.$ day $)$ was used as the amount of groundwater that can be circulated from Kylmäkoski aquifer.

\section{Energy calculations}

Energy calculations were performed in three phases. Firstly, heat power extractable from the groundwater flow (amount of heat, $G$ ) was calculated to describe the potential groundwater heating capacity of Finland. The amount of heat power transportable to a space-heating unit using GWHP systems (total heat load, $H$ ) was then calculated. Thirdly, we calculated an approximation of the equivalent area $\left(\mathrm{m}^{2}\right)$ of residential buildings that could be heated using groundwater heating power. Calculations were performed for each mapped urban and industrial area located inside a groundwater area.

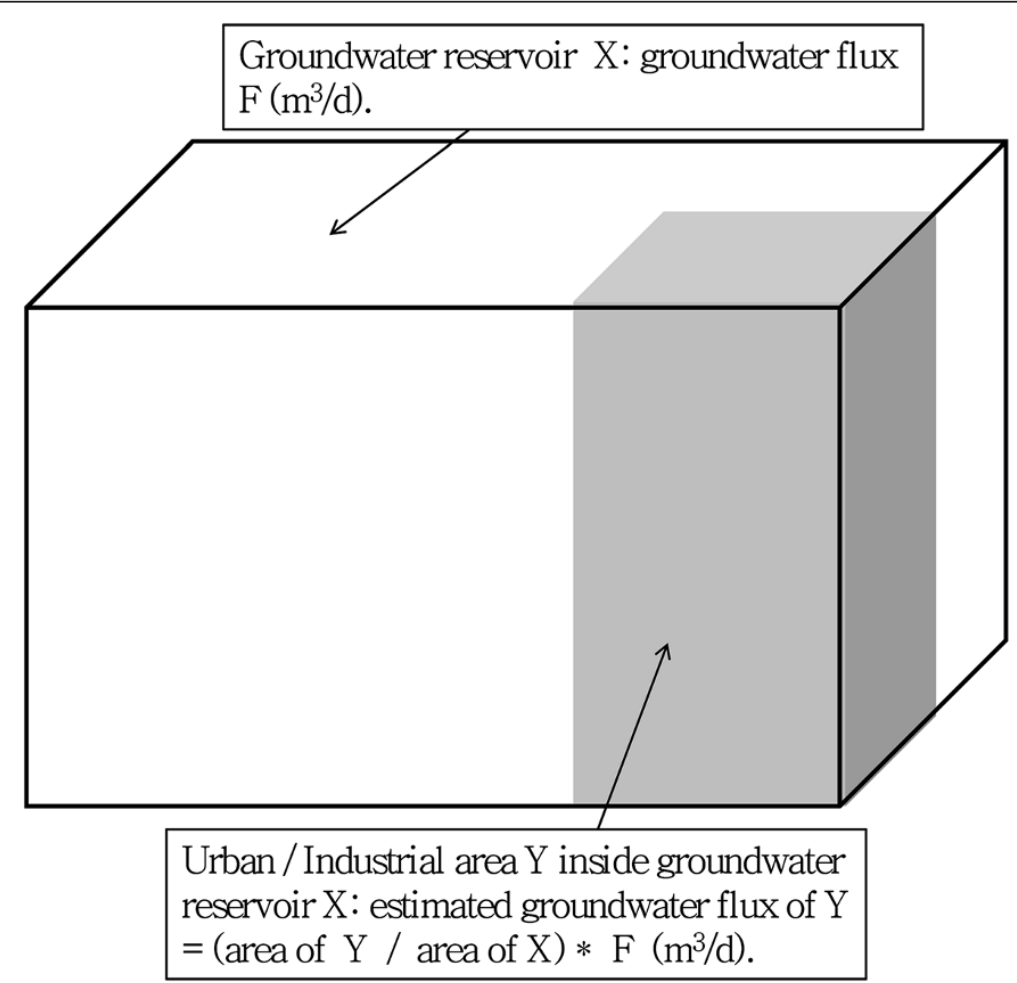

Figure 2 Method for calculating the estimated groundwater flux. An aquifer (area $X$ ) is partly under urban or industrial use (shaded grey, area $Y$ ). The groundwater flux from area $Y$ differs from the entire aquifer's $(X)$ flux. The estimated flux of area $Y$ is calculated by multiplying the proportional land use by the aquifer's recharge. 
The amount of heat $(G)$ extractable from flowing water is

$$
G=F \Delta T S_{v \text { cwat }},
$$

where $F$ = flux of water $(\mathrm{kg} / \mathrm{s})$,

$\Delta T=$ difference between the inlet and outlet temperature in the heat pump $(K)$ and

$S_{V \text { Cwat }}=$ heat capacity of water $(\mathrm{J} / \mathrm{kg} \cdot \mathrm{K})$

(Allen et al. 2003; Allen and Milenic 2003; Banks 2010).

The estimated groundwater flux (see Figure 2) is used as a value of $F$, and $3 \mathrm{~K}$ as a $\Delta T$ value. The value of $4,200 \mathrm{~J} / \mathrm{kg} \cdot \mathrm{K}$ is used as the heat capacity of water. The current value is the heat capacity of water at a temperature of $5^{\circ} \mathrm{C}$ (Yaws 1998).

The amount of heat power that can be produced by a heat pump for a heat distribution system is the heat load $(H)$. Each heat pump has a maximum efficiency level $\left(E_{\max }\right)$, which can be calculated using the idealised Carnot cycle:

$$
E_{\max }=H_{\mathrm{e}} / W=T_{1} /\left(T_{1}-T_{2}\right),
$$

where $H_{\mathrm{e}}=$ delivered amount of energy (J),

$W=$ work done $(\mathrm{J})$,

$T_{1}=$ inlet temperature $(\mathrm{K})$ and

$T_{2}=$ outlet temperature $(\mathrm{K})$

(Heap 1979).

The efficiency of a heat pump is usually referred to as its coefficient of performance $(\mathrm{COP})$. A heat pump is usually powered by electricity $(E)$. Hence, Equation 2 can be rewritten as

$$
\mathrm{COP}=H / E
$$

The energy balance of an electrically driven heat pump is given by

$$
E_{\text {in }}=Q_{\text {out }}+Q_{\mathrm{ls}}-Q_{\text {in }}-k_{\mathrm{ls}, \text { aux }} W_{\mathrm{a}},
$$

where $E_{\text {in }}=$ energy needed to cover the heat requirement of the distribution system $(J)$, $Q_{\text {out }}=$ heat energy requirement of the distribution system $(J)$,

$Q_{\mathrm{ls}}=$ thermal losses of generation system (J),

$Q_{\text {in }}=$ ambient heat energy used as a heat source for the heat pump (J),

$k_{\mathrm{ls}, \mathrm{aux}}=$ recovered fraction of auxiliary energy $(-)$ and

$W_{\mathrm{a}}=$ auxiliary energy input $(\mathrm{J})$

(Standart SFS-EN-15316-4-2 2009).

Assuming that $100 \%$ of the amount of heat is exploitable, that no heat loss occurs in the evaporator of the heat exchanger and that heat from the compressor is delivered efficiently, the heat load $(H)$ can be calculated as

$$
H \approx G+E
$$

where $G$ = amount of heat (W) (see Equation 1), and

$E=$ electric power (W)

(Banks 2010). 
Using COP, $G$ can then be written as

$$
G \approx H(1-1 / \mathrm{COP})
$$

Combining Equations 1 and 6,

$$
\mathrm{H} \approx \mathrm{G}+(\mathrm{H} / \mathrm{COP})=F \Delta T S_{\mathrm{vcwat}} / 1-(1 / \mathrm{COP})
$$

(Allen et al. 2003; Allen \& Milenic 2003; Banks 2010). Equation 7 was used to calculate the heat load in this research. Based on the information provided by Bayer et al. (2011), EHPA (2009) and Saner et al. (2010), a COP of 3.5 was used.

The design power $\left(\mathrm{W} / \mathrm{m}^{2}\right)$ of detached houses and apartment buildings was simulated with the IDA Indoor Climate and Energy (IDA-ICE) 4.1 dynamic simulation tool. The heat demands of different locations were simulated based on the four climatic zones in Finland (Figure 3). Finland is divided into four climatic zones to examine the energy consumption of buildings (National Building Code of Finland 2012). The definition of these climatic zones is mainly based on 30 years of data on annual average air

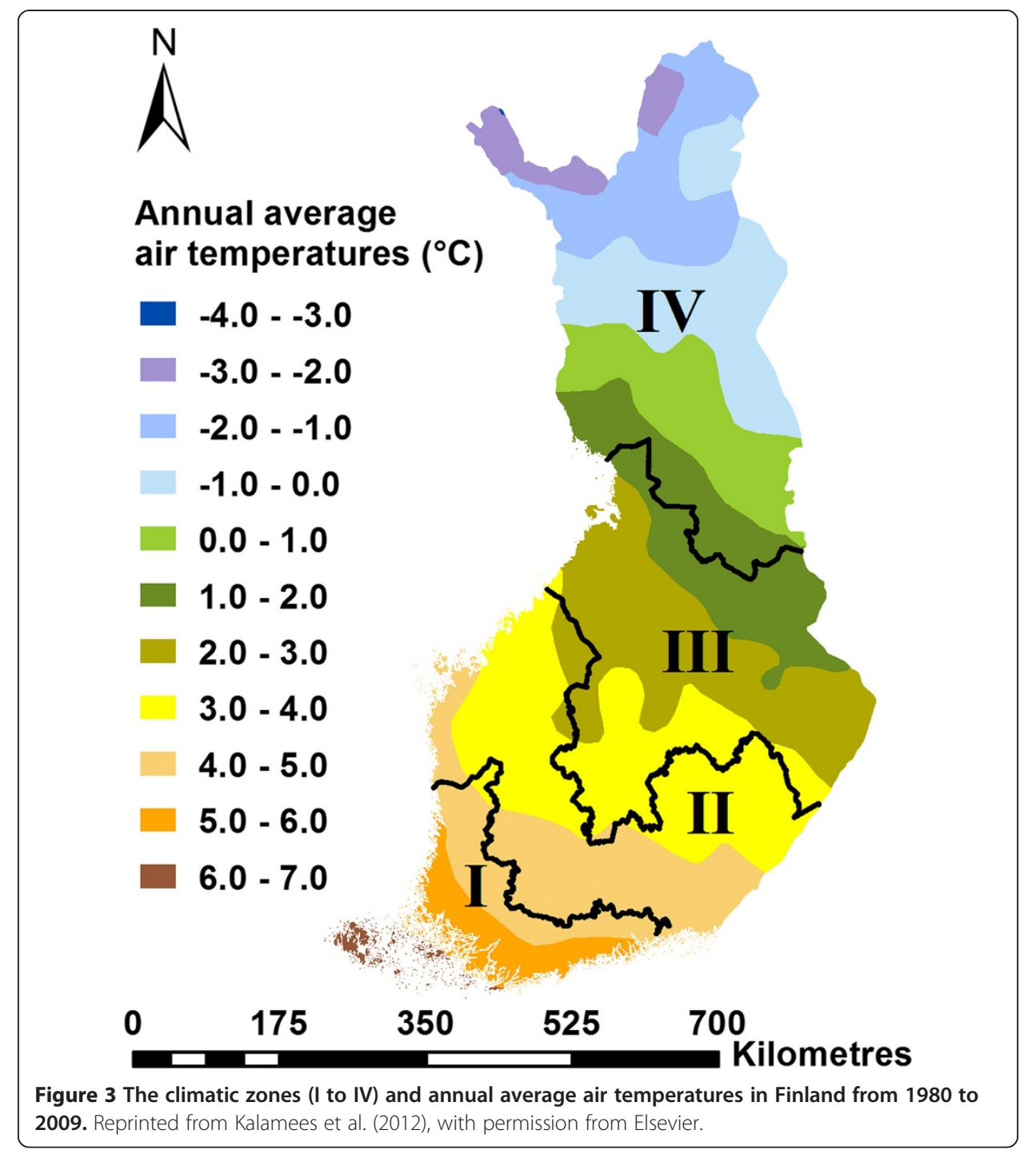


temperatures from representative meteorological stations for each climatic zone (Kalamees et al. 2012). To estimate the surface area of detached houses or apartment buildings that could be heated with power provided by groundwater, the calculated heat load $(H)$ was divided by the design power.

\section{Results and discussion}

Potential areas for groundwater energy utilisation

The groundwater energy database includes 801 groundwater areas, comprising 700 urban and 169 industrial areas. The database indicates that 56,464 ha of Finnish groundwater areas are under urban or industrial land use, and the theoretical groundwater flux of these exploitable areas is 293,291 $\mathrm{m}^{3} /$ day (Table 1). Table 1 provides summary information on the exploitable groundwater reservoirs, and the exploitable area and percentage of the aquifers zoned for industrial and/or urban areas.

A recharge value in the Hertta Database is calculated based on assumptions that precipitation, the hydrological cycle and porosity of soil are constant over the entire aquifer (The Hertta Database 2012). However, in shallow Quaternary aquifers, soil and hydrogeological conditions are not constant; for example, the thickness and foliation of soil layers vary in each aquifer, which cause differences in groundwater flow velocity, direction and percolation. The assumption of constant meteorological and geological conditions in the Hertta Database is the largest source of error in our research, as it affects the utilisable amount of groundwater, which has a direct influence on the amount of heat and the heat load results. As can be noted from Equations 1 and 7, a $10 \%$ error in the $F$ value will create a $10 \%$ error in the $G$ and $H$ values. However, the Hertta Database is the only nationwide database that includes groundwater recharge values, and hence, it was used in this research.

Because of high hydraulic conductivity of Finnish aquifers, it is common to have the Water Rights Court permission to pump 400 to $1,500 \mathrm{~m}^{3}$ groundwater/day from one well (The Hertta Database 2012). In Sweden, in Arlanda airport which is located on a glaciofluvial esker, it is possible to pump 1,570 $\mathrm{m}^{3} /$ day from one well (Persson 2007). High hydraulic conductivity allows also efficient water injection back to the aquifer. The average groundwater flux in our data is $303 \mathrm{~m}^{3} /$ day (Table 1). Hence, well hydraulics will not cause major obstacles to groundwater energy use in Finnish aquifers.

As an equal amount of groundwater is injected into the same aquifer from which it is pumped (see Figure 1), the aquifer-scale water storage budget remains constant, and the sustainable yield value equals the natural recharge value (Zhou 2009). We realise that groundwater utilisation will produce small-scale changes in the water budget

Table 1 Groundwater flux and area summary of the aquifers under urban or industrial land use

\begin{tabular}{lllll}
\hline & $\begin{array}{l}\text { Flux of exploitable } \\
\text { groundwater } \\
\text { reservoir }\left(\mathbf{m}^{\mathbf{3}} / \text { day }\right)\end{array}$ & $\begin{array}{l}\text { Flux of exploitable } \\
\text { groundwater } \\
\text { reservoir }(\mathbf{l} / \mathbf{s})\end{array}$ & $\begin{array}{l}\text { Exploitable area of } \\
\text { the groundwater } \\
\text { reservoir }(\mathbf{h a})\end{array}$ & $\begin{array}{l}\text { Exploitation \% of } \\
\text { the groundwater } \\
\text { reservoir }\end{array}$ \\
\hline Total & 293,291 & 3,395 & 56,464 & \\
Maximum & 13,443 & 156 & 1,809 & 98 \\
Minimum & 0.2 & 0.002 & 0.07 & 0.01 \\
Average & 303 & 4 & 62 & 23 \\
Median & 121 & 1 & 31 & 16 \\
\hline
\end{tabular}


around abstraction and injection wells. Noting the reality that Finnish sand and gravel aquifers provide hydraulic conductivity of $10^{-5}$ to $10^{-2} \mathrm{~m} / \mathrm{s}$ (Salonen et al. 2014; Salonen et al. 2001), the buildings and hence the GWHP systems are planned to have a life cycle of 50 years to a maximum of 100 years. We investigated urban or industrial areas, where natural groundwater conditions have changed due to urbanisation, and it is reasonable to use the natural recharge value, i.e. the maximum sustainable yield (Kalf and Woolley 2005; Zhou 2009) for country-scale GWHP potential calculations. If re-injection was carried out by allowing the groundwater to infiltrate from ponds to the aquifer, evaporation in summer would reduce the amount of injected water, and the natural recharge value could not be used to a further extent. However, in ponds, the melting of snow in spring would increase the amount of injectable water. Hence, the sustainable yield estimation, especially for property-sized projects, cannot be performed without site-specific groundwater investigations. As inter alia, the socioeconomic issues need to be considered when estimating the sustainable yield (Alley and Leake 2004; Sophocleus and Devlin 2004), the possibility of mining groundwater for 50 to 100 years for renewable energy utilisation, especially in urbanised areas, may allow decision makers to accept a larger sustainable yield than the natural recharge of an aquifer. The use of groundwater is controlled and protected by law in Finland, and an environmental permit must be obtained from the Regional State Administrative Agencies to implement a GWHP system if the pumped amount of groundwater exceeds $250 \mathrm{~m}^{3} /$ day (Water Act 2011; Environmental Protection Act 2000). Assuming that groundwater circulation will have no major effects on the groundwater storage, legal permission for GWHP utilisation is easily arguable. We assessed that it is more accurate to use the available recharge information approved by the Finnish Environment Institute than to try to estimate a general sustainable yield multiplier for the GWHP systems in Finland.

Our study focused on the Finnish aquifers that are classified as groundwater areas by the Finnish Environment Institute, as official recharge data are only available for classified aquifers. Nevertheless, the methods used in our study are applicable to all geological or artificial deposits suitable as a source of groundwater energy. Aquifers that are not under urban or industrial land use were excluded from this investigation due to the long energy transportation distances, which makes them economically unattractive to utilise at present. Groundwater areas of the Aland Islands, Kemijärvi's Kattilanvaara (no. 12320171) and Keminmaa's Kiviharju (no. 1224102) were excluded from our research, as no publically available information on recharge exists. The area of Santahamina, Helsinki, was incorrectly designated an industrial area in the Corine 2006 Database, but was changed to an urban area for the groundwater energy database. As the Hertta and Corine databases are in vector format, aquifer borders were used as the cut-off line, and all urban and industrial areas included in the groundwater energy database are therefore situated inside aquifers.

The natural groundwater temperature in Finnish aquifers is quite low, being between $3.5^{\circ} \mathrm{C}$ and $6.6^{\circ} \mathrm{C}$ (Mälkki and Soveri 1986; Oikari 1981). In northern Finland, this temperature can be less than $3.5^{\circ} \mathrm{C}$. Even though groundwater may be easily utilisable in these regions, the relatively low groundwater temperature may significantly reduce the groundwater's heating potential. This study was based on natural groundwater temperatures. However, according to Allen et al. (2003), Ferguson and Woodbury (2004), Zhu et al. (2010) and Kerl et al. (2012), the urban heat island effect has increased 
groundwater temperatures under cities. Elevated subsurface temperatures will enhance the groundwater's heating potential, and it may therefore be possible to utilise groundwater for heating even in a region where the groundwater is naturally cold.

\section{Energy potential}

Our results demonstrate that Finnish aquifers zoned for urban or industrial land use contain $42,772 \mathrm{~kW}$ of heat, $G$. The average heat content of aquifers is $46 \mathrm{~kW}$, the median being $18 \mathrm{~kW}$ (Figure 4). The 90th percentile value is $106 \mathrm{~kW}$, which equals the 95th most potential aquifer. This means that the variability in energy potential is high, especially amongst the most potential aquifers. Hence, a box plot diagram for the 100 most potential is also presented in Figure 4. Most of the potentially utilisable groundwater energy areas are located in southern Finland (Figure 5). This distribution is due to the higher population density in southern than in northern Finland, which affects the land use and drinking water exploitation of aquifers. In Figure 5, $G$ values are divided into four power categories: aquifers in the yellow category contain 1 to $100 \mathrm{~kW}$ of heating power, light orange 100 to $200 \mathrm{~kW}$, dark orange 200 to $500 \mathrm{~kW}$ and red over $500 \mathrm{~kW}$. The $G$ values were used instead of $H$ values in Figure 5, as $H$ values are highly dependent on heat pump efficiency and will vary as heat pump technology develops over time. Hence, $G$ values describe the potential heating power that could be utilised from flowing groundwater.

The aquifer with the best potential, Lahti, has an almost 2.5 times greater heating potential than the second best, Koskenkorva (Table 2). The Lahti aquifer has been zoned for both urban and industrial land, with a total heating potential of 2,700 kW, being $36.5 \%$ of the total heating potential of the top ten aquifers in Finland. The city of Lahti is the largest city on the Salpausselkä I formation (Statistical Finland 2013), located on the confluence of two ancient ice lobes, the Baltic and Lake Finland ice lobes (Punkari 1982). Hence, large areas in urban and industrial use on the top of the most extensive aquifer explain the results from the energy potential calculations. Table 2 also presents the amount of heat extractable from 1 ha for each aquifer. As the area of point-sized groundwater areas is zero in the Hertta Database, the power/hectare value cannot be calculated for these aquifers. Differences of over tenfold exist between the top 20 aquifers in the amount of heat utilisable from 1 ha. In total, 16 of the 20 aquifers with the best potential are zoned for urban land use.

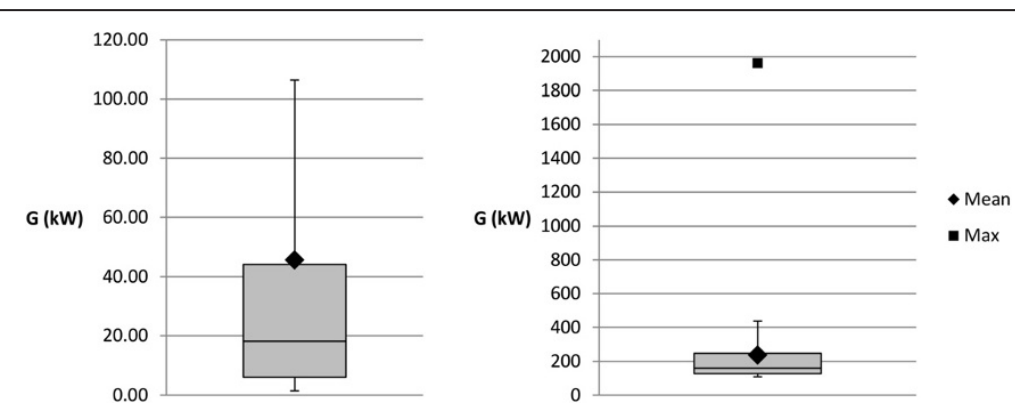

Figure 4 Distribution of the calculated amount of heat $(G)$. The data for all aquifers are on the left, and the 100 most potential aquifers on the right. The boxes indicate the 25th and 75th percentiles and median. Whiskers indicate the 10th percentile (lower) and 90th percentile (upper). The mean value (both diagrams) and maximum (right) are also presented. 


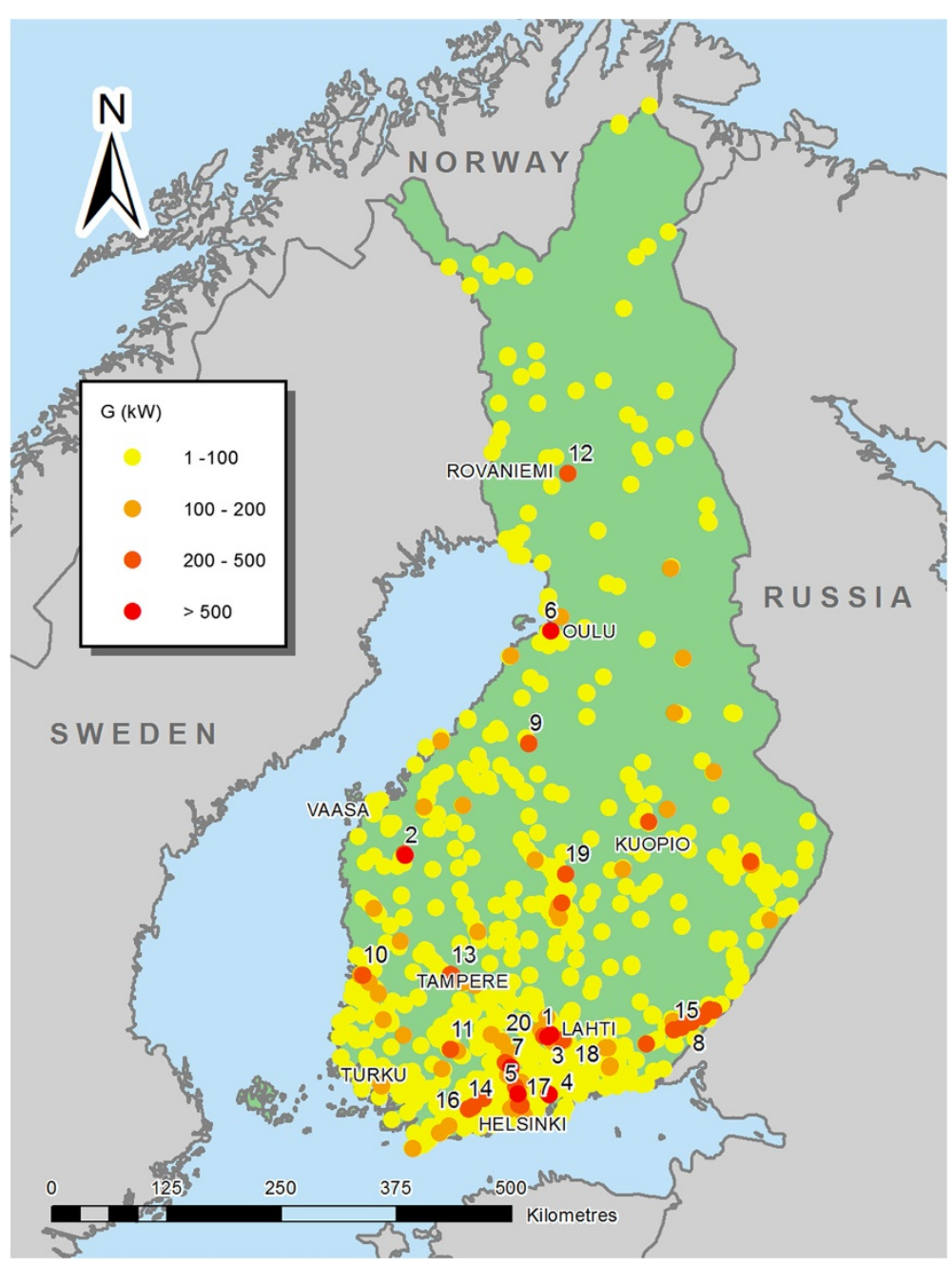

Figure 5 Potential aquifers for GWHP energy utilisation in Finland. Each dot represents a single aquifer. The dot colour indicates the categorised amount of heat (G). Numbers from 1 to 20 indicate the location of the 20 aquifers with the largest potential. (Basemap Database@ Esri, DeLorme, Navteq and Natural Earth).

We used $3 \mathrm{~K}$ as the value of $\Delta T$, because Finnish groundwater water will not usually freeze, even if $3 \mathrm{~K}$ is extracted. This is a conservative figure, and a higher $\Delta T$ could be used in many cases, especially in southern Finland. Noting the study of Brielmann et al. (2009), there appear to be no environmental barriers to $3 \mathrm{~K}$ groundwater energy utilisation. There is no known measured information on the COP from Finnish GWHP systems, and hence, we used a literature value for the COP. According to the literature presented by Allen et al. (2003), Banks (2010), Lund et al. (2004) and Warren (1994), the COP has been between 3 and 6 for most GWHP sites. The COP value describes the efficiency of a heat pump in any given time frame. Hence, the COP in winter can vary significantly from that in summer. The efficiency of a heat pump over a year is measured by the seasonal performance factor (SPF). The SPF is highly dependent on site characteristics such as the geology, climate and geothermal gradient (Bayer et al. 2011), which vary significantly between the areas of Finland. The total energy efficiency of heating systems, not just the heat pump consumption, can be described by the system seasonal performance factor (SSPF) (Banks 2010). Saner et al. (2010) proposed 
Table 2 Selected groundwater areas ranked according to the amount of heat (G) exploitable

\begin{tabular}{|c|c|c|c|c|c|c|}
\hline $\begin{array}{l}\text { Groundwater } \\
\text { area code }\end{array}$ & $\begin{array}{l}\text { Groundwater } \\
\text { area name }\end{array}$ & Municipality & $\begin{array}{l}\text { Land use of the } \\
\text { groundwater } \\
\text { area }\end{array}$ & $\begin{array}{l}\text { Amount } \\
\text { of heat }(G) \\
(\mathrm{kW})\end{array}$ & $\begin{array}{l}\text { Amount of } \\
\text { heat }(G) \\
\mathrm{kW} / \mathrm{ha}\end{array}$ & $\begin{array}{l}\text { Rank } \\
\text { number }\end{array}$ \\
\hline 0439801 & Lahti & Lahti & Urban & $1,960.44$ & 1.08 & 1 \\
\hline 1014503 & Koskenkorva & IImajoki & Urban & 798.53 & 4.07 & 2 \\
\hline 0439801 & Lahti & Lahti & Industrial & 733.25 & 1.08 & 3 \\
\hline $0161251 \mathrm{~A}$ & Porvoo & Porvoo & Urban & 717.97 & 4.32 & 4 \\
\hline 0185803 & Rusutjärvi & Tuusula & Urban & 698.40 & 4.93 & 5 \\
\hline 11244001 & Kempeleenharju & Kempele & Urban & 670.40 & 0.38 & 6 \\
\hline 0110651 & Hyvinkää & Hyvinkää & Urban & 502.91 & 0.55 & 7 \\
\hline 0517351 A & Joutsenonkangas & Lappeenranta & Urban & 467.25 & 0.87 & 8 \\
\hline 1153503 & Hitura* & Nivala & Industrial & 437.50 & & 9 \\
\hline 0260903 & Karjaranta* & Pori & Urban & 437.50 & & 10 \\
\hline 0406101 & Vieremä & Forssa & Urban & 437.18 & 2.17 & 11 \\
\hline 1269802 & Kolpene & Rovaniemi & Urban & 414.62 & 1.44 & 12 \\
\hline 0498051 & Ylöjärvenharju & Ylöjärvi & Urban & 394.14 & 1.15 & 13 \\
\hline 0142851 & Tytyri* & Lohja & Industrial & 364.58 & & 14 \\
\hline $0540501 \mathrm{~A}$ & Huhtiniemi & Lappeenranta & Urban & 353.73 & 0.78 & 15 \\
\hline 0142851 B & Lohjanharju & Lohja & Urban & 346.94 & 0.47 & 16 \\
\hline 0109201 & Valkealähde & Vantaa & Industrial & 342.71 & 0.90 & 17 \\
\hline 0453252 A & Nastonharju-Uusikylä & Nastola & Urban & 338.04 & 0.69 & 18 \\
\hline 0977401 & Mutapohja & Äänekoski & Urban & 322.98 & 5.76 & 19 \\
\hline 0409852 & Salpakangas & Hollola & Urban & 313.75 & 0.82 & 20 \\
\hline 0285301 & Kupittaa* & Turku & Urban & 102.08 & & 100 \\
\hline 0431601 A & Järvelä 1 & Kärkölä & Urban & 54.64 & 0.69 & 200 \\
\hline 1054551 & Horonkylä & Teuva & Urban & 33.12 & 0.58 & 300 \\
\hline 0250302 & Tursunperä & Mynämäki & Urban & 22.30 & 0.52 & 400 \\
\hline 0214302 & Heinistö & Ikaalinen & Urban & 16.12 & 0.39 & 500 \\
\hline
\end{tabular}

The 20 areas with the largest groundwater heating energy potential, as well as the areas ranked 100th, 200th, 300th, 400th and 500th in potential. The code and name along with the land use of the groundwater area and the name of the municipality are presented. *Denotes a point-sized groundwater area.

an average SPF of 3.5 for heat pumps. EHPA (2009) suggests an SPF value of 3.2 for Scandinavia. As heat pump technology has evolved during recent decades, the SPF ratio has continuously improved (Bayer et al. 2011), and hence, we used a COP of 3.5. The $\mathrm{COP}$ is preferred in this article, as the calculations are not site or system specific, and neither the SPF nor the SSPF can therefore be measured.

\section{Design power simulations}

To calculate the area $\left(\mathrm{m}^{2}\right)$ of buildings that could be heated using groundwater energy, the quantity of heating energy, i.e. the design power, has to be known. The design principles and results of the IDA-ICE 4.1 simulations are presented in Table 3. The minimum outside temperature presented in Table 3 represents the climate that the designer should use in energy calculations to achieve the minimum energy performance requirements of buildings (Kalamees et al. 2012). Three different building classes, defined by the construction method and time, were simulated. The simulation results 
Table 3 The results of design power simulations

\begin{tabular}{|c|c|c|c|c|c|c|c|c|}
\hline \multirow{2}{*}{\multicolumn{5}{|c|}{$\begin{array}{l}\text { Climatic zone I } \\
\text { (minimum outside temperature }=-26 \mathrm{C} \text { ) }\end{array}$}} & \multirow{2}{*}{\multicolumn{4}{|c|}{$\begin{array}{l}\text { Climatic zone II } \\
\text { (minimum outside temperature }=-29 \mathrm{C})\end{array}$}} \\
\hline & & & & & & & & \\
\hline \multirow[t]{3}{*}{ Class } & \multirow{2}{*}{\multicolumn{2}{|c|}{$\frac{\text { Detached house }}{\text { Design power }\left(\mathrm{W} / \mathrm{m}^{2}\right)}$}} & \multirow{2}{*}{\multicolumn{2}{|c|}{$\frac{\text { Apartment building }}{\text { Design power }\left(\mathrm{W} / \mathrm{m}^{2}\right)}$}} & \multirow{2}{*}{\multicolumn{2}{|c|}{$\begin{array}{l}\text { Detached house } \\
\text { Design power }\left(\mathrm{W} / \mathrm{m}^{2}\right)\end{array}$}} & \multirow{2}{*}{\multicolumn{2}{|c|}{$\frac{\text { Apartment building }}{\text { Design power }\left(\mathrm{W} / \mathrm{m}^{2}\right)}$}} \\
\hline & & & & & & & & \\
\hline & Heating & $\begin{array}{l}\text { Re-heating } \\
\text { of air supply } \\
\text { unit }\end{array}$ & Heating & $\begin{array}{l}\text { Re-heating } \\
\text { of air supply } \\
\text { unit }\end{array}$ & Heating & $\begin{array}{l}\text { Re-heating } \\
\text { of air supply } \\
\text { unit }\end{array}$ & Heating & $\begin{array}{l}\text { Re-heating } \\
\text { of air supply } \\
\text { unit }\end{array}$ \\
\hline $\bar{A}$ & 97 & - & 65 & - & 103 & - & 69 & - \\
\hline B & 34 & 9 & 16 & 12 & 36 & 10 & 17 & 13 \\
\hline C & 25 & 7 & 12 & 10 & 26 & 8 & 13 & 11 \\
\hline \multicolumn{5}{|c|}{ Climatic zone III } & \multicolumn{4}{|c|}{ Climatic zone IV } \\
\hline \multicolumn{5}{|c|}{ (minimum outside temperature $=-32 \mathrm{C}$ ) } & \multicolumn{4}{|c|}{ (minimum outside temperature $=-38 \mathrm{C}$ ) } \\
\hline \multirow[t]{3}{*}{ Class } & \multicolumn{2}{|c|}{ Detached house } & \multicolumn{2}{|c|}{ Apartment building } & \multicolumn{2}{|c|}{ Detached house } & \multicolumn{2}{|c|}{ Apartment building } \\
\hline & \multicolumn{2}{|c|}{ Design power $\left(\mathrm{W} / \mathrm{m}^{2}\right)$} & \multicolumn{2}{|c|}{ Design power $\left(\mathrm{W} / \mathrm{m}^{2}\right)$} & \multicolumn{2}{|c|}{ Design power $\left(\mathrm{W} / \mathrm{m}^{2}\right)$} & \multicolumn{2}{|c|}{ Design power $\left(\mathrm{W} / \mathrm{m}^{2}\right)$} \\
\hline & Heating & $\begin{array}{l}\text { Re-heating } \\
\text { of air supply } \\
\text { unit }\end{array}$ & Heating & $\begin{array}{l}\text { Re-heating } \\
\text { of air supply } \\
\text { unit }\end{array}$ & Heating & $\begin{array}{l}\text { Re-heating } \\
\text { of air supply } \\
\text { unit }\end{array}$ & Heating & $\begin{array}{l}\text { Re-heating } \\
\text { of air supply } \\
\text { unit }\end{array}$ \\
\hline A & 109 & - & 74 & - & 121 & - & 82 & - \\
\hline B & 38 & 11 & 18 & 15 & 42 & 14 & 20 & 17 \\
\hline C & 28 & 10 & 14 & 12 & 31 & 12 & 15 & 15 \\
\hline
\end{tabular}

The results are divided according to the four climate zone categories in Finland, and the design power is calculated separately for detached houses and apartment buildings. The outside temperature limit for the design is according to the National Building Code of Finland (2012). Class definition: A = House or apartment building built before 1960. Ventilation: natural ventilation, air exchange rate $0.4 \mathrm{l} / \mathrm{h}$. Heat distribution system: water radiators $70 / 40^{\circ} \mathrm{C}$. $\mathrm{B}=\mathrm{Thermal}$ insulation according the minimum requirement of the National building code of Finland (2010). Ventilation: mechanical supply and exhaust with heat recovery, air exchange rate $0.5 \mathrm{l} / \mathrm{h}$. Temperature ratio of supplied air is 0.6 . Air tightness rate (n50) in detached house $2.0 \mathrm{l} / \mathrm{h}$ and apartment building $0.7 \mathrm{l} / \mathrm{h}$. Heat distribution system in detached house by hydronic floor heating (design temperatures $40^{\circ} \mathrm{C} / 30^{\circ} \mathrm{C}$ ), in apartment building hydronic radiators (design temperatures $70^{\circ} \mathrm{C} / 40^{\circ} \mathrm{C}$ ). $\mathrm{C}=$ Ultra-low energy building. Ventilation: mechanical supply and exhaust with heat recovery, air exchange rate $0.5 \mathrm{l} / \mathrm{h}$. Temperature ratio of supplied air is 0.85 . Air tightness rate $(\mathrm{n} 50)$ in detached house $0.6 \mathrm{l} / \mathrm{h}$ and apartment building $0.6 \mathrm{l} / \mathrm{h}$. Heat distribution system in detached house by hydronic floor heating (design temperatures $40^{\circ} \mathrm{C} / 30^{\circ} \mathrm{C}$ ), in apartment building hydronic radiators (design temperatures $70^{\circ} \mathrm{C} / 40^{\circ} \mathrm{C}$ ).

indicated that $20 \%$ to $27 \%$ less design power is needed in buildings situated in climate zone I compared to those in climate zone IV. The power for re-heating of the air supply unit is reported in the table and added to the total power needs in further calculations. Household hot water consumption is not included in the design power, as it is assumed that houses and buildings have water boilers that can be heated during off-peak conditions.

Design power simulations were carried out for residential buildings only, as in industrial buildings, the energy demands vary significantly and no suitable averages exist for describing their energy use. However, industrial areas are included in the surface area calculations in our article (Table 4). Therefore, calculations for industrial buildings are theoretical but are used to illustrate the potential for groundwater energy utilisation.

\section{Adequacy of groundwater power}

According to our results, 59,880 $\mathrm{kW}$ of heat load $(H)$ could be utilised from Finnish aquifers that are zoned for urban or industrial land use. The $H$ value describes the heating power that can be distributed to buildings from the groundwater heating potential (amount of heat, G) using heat pumps. Knowing the design power $\left(\mathrm{W} / \mathrm{m}^{2}\right)$ and heat load (W), it is possible to calculate the heating area of buildings. The heat load $(H)$ results for aquifers showed a similar distribution of magnitude to the amount of heat 
Table 4 Selected results from energy adequacy calculations

\begin{tabular}{|c|c|c|c|c|c|c|c|c|c|c|c|c|}
\hline \multirow{2}{*}{$\begin{array}{l}\text { Groundwater } \\
\text { area code }\end{array}$} & \multirow{2}{*}{$\begin{array}{l}\text { Groundwater } \\
\text { area name }\end{array}$} & \multirow[t]{2}{*}{ Municipality } & \multirow{2}{*}{$\begin{array}{l}\text { Land use of the } \\
\text { groundwater area }\end{array}$} & \multirow{2}{*}{$\begin{array}{l}\text { Total heat } \\
\text { load }(H) \\
\text { (kW) }\end{array}$} & \multirow{2}{*}{$\begin{array}{l}\text { Climatic } \\
\text { zone }\end{array}$} & \multicolumn{6}{|c|}{ Heating surface area $\left(\mathrm{m}^{2}\right)$} & \multirow[t]{2}{*}{ Rank number } \\
\hline & & & & & & $\begin{array}{l}\text { Detached } \\
\text { house, } \\
\text { class A }\end{array}$ & $\begin{array}{l}\text { Detached } \\
\text { house, } \\
\text { class B }\end{array}$ & $\begin{array}{l}\text { Detached } \\
\text { house, } \\
\text { class C }\end{array}$ & $\begin{array}{l}\text { Apartment } \\
\text { building, } \\
\text { class A }\end{array}$ & $\begin{array}{l}\text { Apartment } \\
\text { building, } \\
\text { class B }\end{array}$ & $\begin{array}{l}\text { Apartment } \\
\text { building, } \\
\text { class C }\end{array}$ & \\
\hline 0439801 & Lahti & Lahti & Urban & $2,744.61$ & $\|$ & 26,554 & 59,054 & 78,850 & 39,526 & 89,605 & 114,537 & 1 \\
\hline 1014503 & Koskenkorva & IImajoki & Urban & $1,117.94$ & $\|$ & 10,816 & 24,054 & 32,117 & 16,100 & 36,498 & 46,653 & 2 \\
\hline $0161251 \mathrm{~A}$ & Porvoo & Porvoo & Urban & $1,005.16$ & । & 10,326 & 23,188 & 31,154 & 15,408 & 35,572 & 46,004 & 3 \\
\hline 0185803 & Rusutjärvi & Tuusula & Urban & 977.75 & । & 10,045 & 22,556 & 30,305 & 14,988 & 34,602 & 44,749 & 4 \\
\hline 0439801 & Lahti & Lahti & Industrial & $1,026.55$ & $\|$ & 9,932 & 22,087 & 29,492 & 14,784 & 33,514 & 42,840 & 5 \\
\hline 11244001 & Kempeleenharju & Kempele & Urban & 938.55 & $\|$ & 8,581 & 18,920 & 25,127 & 12,745 & 28,438 & 35,990 & 6 \\
\hline 0110651 & Hyvinkää & Hyvinkää & Urban & 704.07 & $\|$ & 6,812 & 15,149 & 20,227 & 10,139 & 22,986 & 29,382 & 7 \\
\hline 0517351 A & Joutsenonkangas & Lappeenranta & Urban & 654.15 & $\|$ & 6,329 & 14,075 & 18,793 & 9,421 & 21,356 & 27,299 & 8 \\
\hline 0260903 & Karjaranta* & Pori & Urban & 612.50 & । & 6,292 & 14,130 & 18,984 & 9,389 & 21,676 & 28,033 & 9 \\
\hline 0406101 & Vieremä & Forssa & Urban & 612.05 & $\|$ & 5,922 & 13,169 & 17,584 & 8,814 & 19,982 & 25,542 & 10 \\
\hline 1153503 & Hitura* & Nivala & Industrial & 612.50 & III & 5,600 & 12,347 & 16,398 & 8,317 & 18,559 & 23,487 & 11 \\
\hline 0498051 & Ylöjärvenharju & Ylöjärvi & Urban & 551.80 & $\|$ & 5,339 & 11,873 & 15,853 & 7,947 & 18,015 & 23,028 & 12 \\
\hline 0142851 & Tytyri* & Lohja & Industrial & 510.42 & । & 5,244 & 11,775 & 15,820 & 7,824 & 18,063 & 23,361 & 13 \\
\hline 0142851 B & Lohjanharju & Lohja & Urban & 485.71 & । & 4,990 & 11,205 & 15,054 & 7,446 & 17,189 & 22,230 & 14 \\
\hline 0109201 & Valkealähde & Vantaa & Industrial & 479.79 & । & 4,929 & 11,068 & 14,871 & 7,355 & 16,979 & 21,959 & 15 \\
\hline $0540501 \mathrm{~A}$ & Huhtiniemi & Lappeenranta & Urban & 495.22 & $\|$ & 4,791 & 10,655 & 14,227 & 7,132 & 16,168 & 20,666 & 16 \\
\hline 1269802 & Kolpene & Rovaniemi & Urban & 580.47 & IV & 4,781 & 10,393 & 13,677 & 7,075 & 15,383 & 13,686 & 17 \\
\hline 0453252 A & Nastonharju-Uusikylä & Nastola & Urban & 473.26 & $\|$ & 4,579 & 10,183 & 13,596 & 6,815 & 15,451 & 19,750 & 18 \\
\hline 0409852 & Salpakangas & Hollola & Urban & 439.26 & $\|$ & 4,250 & 9,451 & 12,619 & 6,326 & 14,341 & 18,331 & 19 \\
\hline 0977401 & Mutapohja & Äänekoski & Urban & 452.18 & $\|$ & 4,134 & 9,115 & 12,106 & 6,140 & 13,701 & 17,339 & 20 \\
\hline
\end{tabular}


Table 4 Selected results from energy adequacy calculations (Continued)

\begin{tabular}{|c|c|c|c|c|c|c|c|c|c|c|c|c|}
\hline 0409851 & Kukonkoivu-Hatsina & Hollola & Urban & 140.57 & $\|$ & 1,360 & 3,025 & 4,038 & 2,024 & 4,589 & 5,866 & 100 \\
\hline 0293252 & Vilpeenharju & Ylöjärvi & Urban & 75.19 & $\|$ & 727 & 1,618 & 2,160 & 1,083 & 2,455 & 3,138 & 200 \\
\hline 0260901 & Ulasoori-Vähärauma & Pori & Industrial & 42.58 & 1 & 437 & 982 & 1,320 & 653 & 1,507 & 1,949 & 300 \\
\hline 0575412 & Pappila & Kouvola & Urban & 31.35 & $\|$ & 303 & 675 & 901 & 452 & 1,024 & 1,308 & 400 \\
\hline 0941012 & Vihtavuori & Laukaa & Industrial & 24.03 & III & 220 & 484 & 643 & 326 & 728 & 921 & 500 \\
\hline
\end{tabular}

The table shows the 20 areas with the greatest groundwater power adequacy as well as the areas ranked 100th, 200th, 300th, 400th, and 500th. *Denotes a point-sized groundwater area. Building classification is according to Table 3 , and the climate zone according to Figure 3. 
$(G)$, because heat load calculations are based on a constant COP of 3.5. The COP value is highly dependent on evaporation and condensation temperature differences in a heat pump. Therefore, the groundwater temperature will affect the COP value. In Table 4, aquifers are ranked according to their ability to heat buildings, which, because of the design power, is location dependent. Hence, an aquifer's ranking number in Table 4 may differ from that in Table 2. The only scientifically reported Finnish GWHP system, that utilising the Vieremä aquifer in the municipality of Forssa, employed 0.5-MW heat pumps (Iihola et al. 1988; Iihola and Laitinen 1984). According to our database, a heat load of $621 \mathrm{~kW}$ could be utilised from the Vieremä aquifer. Hence, our theoretical heat load calculations showed a high degree of comparability with practical experience in the Vieremä aquifer. We also ranked Vieremä aquifer in the 10th place in Finland in terms of its potential for heat energy utilisation.

With the power of $59,880 \mathrm{~kW}$, approximately $580,000 \mathrm{~m}^{2}$ of houses in category A, almost 1.3 million $\mathrm{m}^{2}$ in category $\mathrm{B}$ and almost 1.73 million $\mathrm{m}^{2}$ of category $\mathrm{C}$ houses could be heated (Table 5). The average volume of building permits for residential houses was 12.4 million $\mathrm{m}^{3}$ in 2011 to 2013 (Official Statistics of Finland 2014), and the minimum room height is $250 \mathrm{~cm}$ in Finland (National Building Code of Finland 2005). Hence, we can estimate that $25 \%$ to $40 \%$ of annually constructed residential buildings could be heated utilising groundwater energy. In Table 5, building category A corresponds to buildings built before 1960, for which, depending on the climate zone, the design power of houses is 97 to $121 \mathrm{~W} / \mathrm{m}^{2}$ and that of apartments is 65 to $82 \mathrm{~W} / \mathrm{m}^{2}$. Category B represents standard buildings with thermal insulation built according to the National Building Code D3. The design power of category B houses is 43 to $56 \mathrm{~W} / \mathrm{m}^{2}$ and that of apartments is 28 to $37 \mathrm{~W} / \mathrm{m}^{2}$. Category C represents modern ultra-low energy buildings, for which the design power of houses is 32 to $43 \mathrm{~W} / \mathrm{m}^{2}$ and that of apartments is 22 to $30 \mathrm{~W} / \mathrm{m}^{2}$. The total is a summary of 801 groundwater areas. The average heating area of category B houses is $1,380 \mathrm{~m}^{2}$ and that of apartments is 2,097 $\mathrm{m}^{2}$ (Figure 6). The

Table 5 Building surface area $\left(\mathrm{m}^{2}\right)$ that can be heated using groundwater energy

\begin{tabular}{cllllll}
\hline & $\begin{array}{l}\text { Detached } \\
\text { house, } \\
\text { class A }\end{array}$ & $\begin{array}{l}\text { Detached } \\
\text { house, } \\
\text { class B }\end{array}$ & $\begin{array}{l}\text { Detached } \\
\text { house, } \\
\text { class C }\end{array}$ & $\begin{array}{l}\text { Apartment } \\
\text { building, } \\
\text { class A }\end{array}$ & $\begin{array}{l}\text { Apartment } \\
\text { building, } \\
\text { class B }\end{array}$ & $\begin{array}{l}\text { Apartment } \\
\text { building, } \\
\text { class C }\end{array}$ \\
\hline Total & 580,981 & $1,293,186$ & $1,727,772$ & 864,968 & $1,964,827$ & $2,493,992$ \\
Maximum area/aquifer & 26,554 & 59,054 & 78,850 & 39,526 & 89,605 & 114,537 \\
Minimum area/aquifer & 0.4 & 1 & 1 & 1 & 1 & 1 \\
Average area/aquifer & 620 & 1,380 & 1,844 & 923 & 2,097 & 2,662 \\
Median area/aquifer & 246 & 549 & 734 & 366 & 834 & 1,035 \\
Class & Design power (W/m²)/climate zone & & & \\
Detached house & I & II & III & IV & & \\
A & 97 & 103 & 109 & 121 & & \\
B & 43 & 46 & 49 & 56 & & \\
C & 32 & 34 & 38 & 43 & & \\
Apartment building & & & & & & \\
A & 65 & 69 & 74 & 82 & & \\
B & 28 & 30 & 33 & 37 & & \\
C & 22 & 24 & 26 & 30 & & \\
\hline
\end{tabular}

The design power values used for house and apartment classes for each climate zone are presented below the results. 


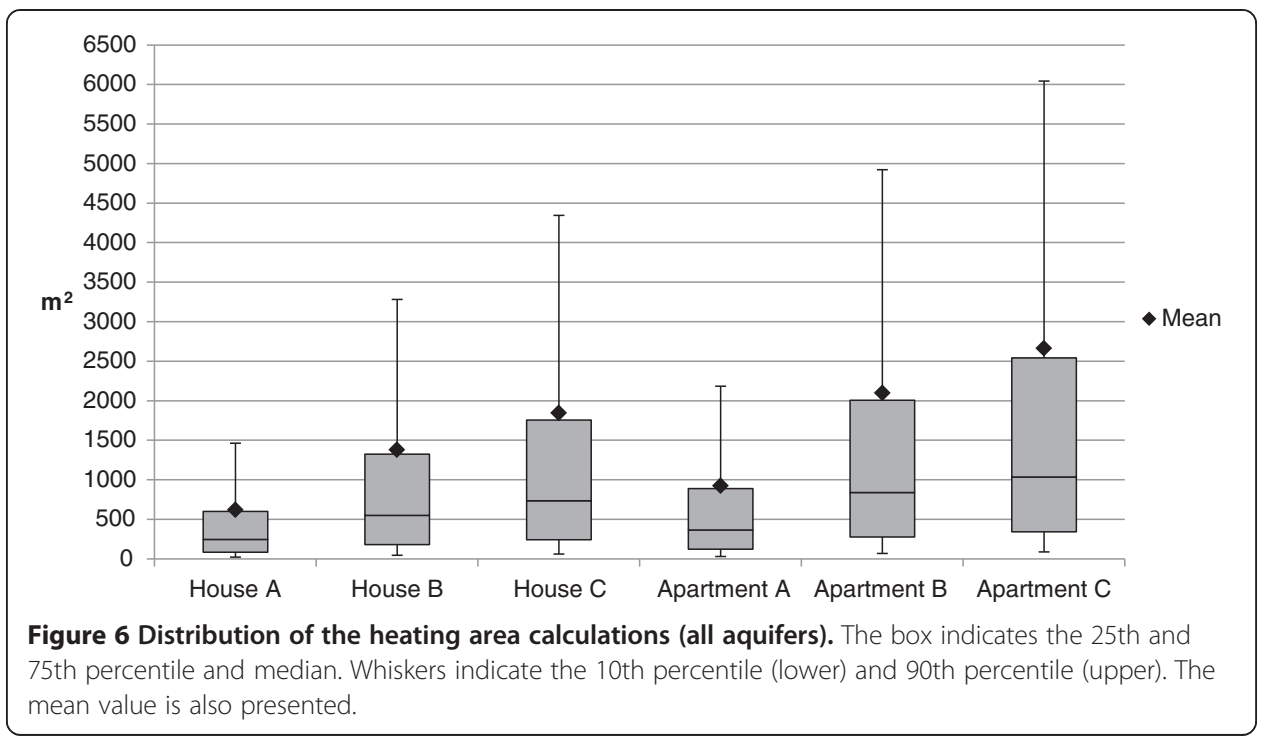

median and maximum values are approximately 2.2 to 2.3 times greater in category $\mathrm{B}$ buildings than those in category $\mathrm{A}$, and 2.8 to 3.0 times greater in category $\mathrm{C}$ than those in category A (Figures 6 and 7). The ability to heat varies significantly between the largest aquifers. The 90th percentile equals the 95 th to the 97 th most potential aquifers. Hence, a box plot diagram for the top 100 aquifers is presented in Figure 7.

There are several hundred sites where GWHP could provide an additional solution for energy utilisation in Finland. Assuming that $100 \%$ of the heat is produced by a GWHP, 368 aquifers would provide the possibility to heat over $1,000 \mathrm{~m}^{2}$ of class C detached houses. Similarly, 365 aquifers could provide heat for class $\mathrm{C}$ apartment buildings with a surface area of over $1,500 \mathrm{~m}^{2}$. In most cases, thermogeological heating systems are not cost effective if they are designed to supply the maximum heat demand. The most effective solution, both environmentally and economically, is to design a heat pump system to fulfil $50 \%$ to $60 \%$ of the peak heat demand (Holopainen et al. 2010;

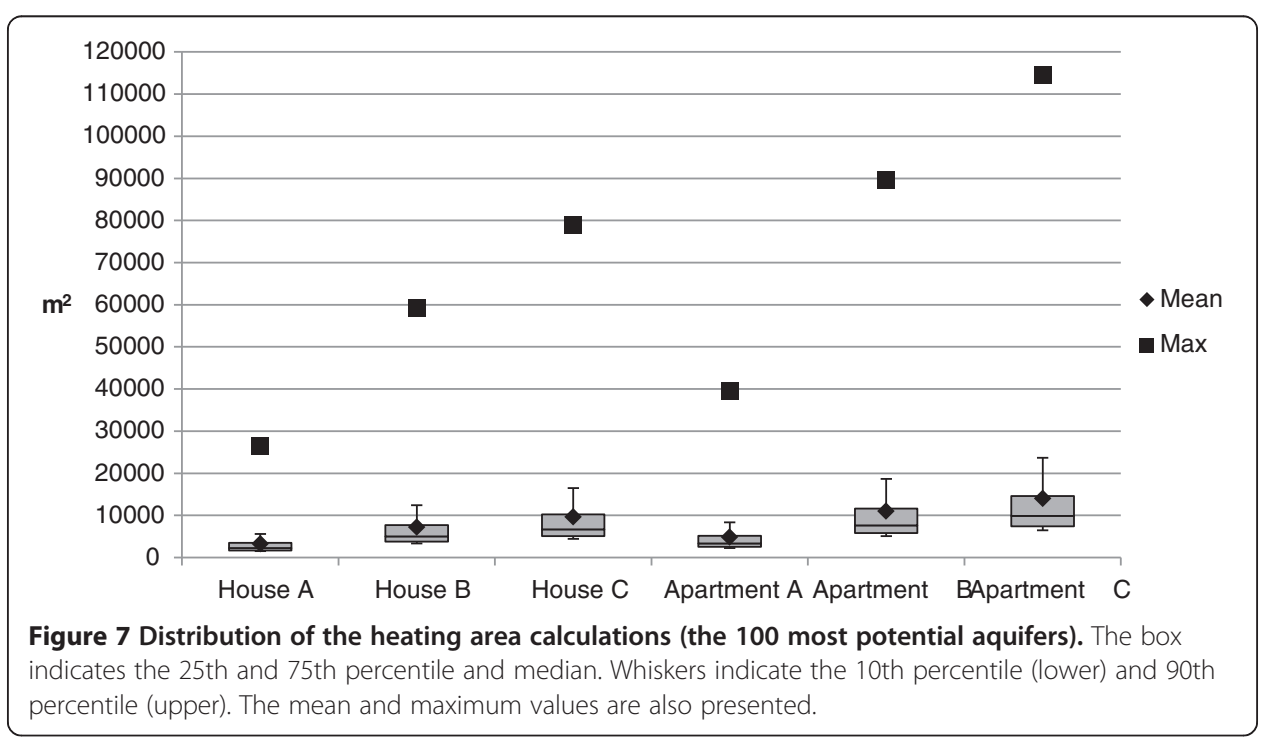


Rosen et al. 2001). Considering this, our results are conservative, but indicate the potential to utilise renewable energy.

Using Equation 7 , applying the parameters $\left(\Delta T, \mathrm{COP}\right.$, and $\left.\mathrm{S}_{\mathrm{VCwat}} \mathrm{s}\right)$ used in this research and making a highly theoretical estimation that all replenished groundwater from Finnish categorised aquifers (5.4 million $\mathrm{m}^{3} /$ day, The Hertta Database (2012), corresponds to the $F$ value) could be pumped through a heat pump, almost 1,200 MW of heat load $(H)$ could be produced by using GWHP systems. This amount of power could be used to heat over 20 million $\mathrm{m}^{2}$ of housing and is approximately $70 \%$ of the net power produced by both OL1 and OL2 nuclear reactors of the Olkiluoto nuclear power station in Western Finland (Ministry of Employment and the Economy 2011).

The methodology we present this paper could easily be implemented in other countries or states to investigate the large-scale geothermal potential of aquifers. This methodology and the results could also be used as a preliminary mapping tool to identify the aquifers with the greatest potential for energy utilisation in a particular region. However, the reliability of the results is dependent on accurate estimation of hydrogeological and land use information.

\section{Conclusions}

Groundwater can be a significant local source of renewable energy in Finland. Because GWHP systems are internationally recognised to utilise renewable energy, and groundwater is easily exploitable from shallow sedimentary aquifers, it is an attractive option for energy use and should also be recognised in Finland. Groundwater energy utilisation is dependent on the existence of geologically and geochemically suitable aquifers that are zoned for urban or industrial land use and are only located in certain parts of the country. Hence, groundwater energy cannot provide a nationwide source of heating energy in Finland. This article is focused on the heating perspective, but the discussion is equally valid for cooling applications.

Approximately 56,500 ha of classified Finnish aquifers, comprising 801 groundwater areas, are under urban or industrial land use. According to the analysis presented here, the groundwater of these urban and industrial areas contains 40 to $45 \mathrm{MW}$ of heating power. Assuming a COP of 3.5, 55 to $60 \mathrm{MW}$ of heating power could be utilised from these aquifers using heat pumps. With this amount of power, almost 1.3 million $\mathrm{m}^{2}$ of standard detached housing and over 1.7 million $\mathrm{m}^{2}$ of modern ultra-low energy detached housing could be heated by GWHP systems.

Because of the estimated groundwater flux we used, the results are conservative, and the amount of thermogeological energy that could be provided by groundwater may be higher than presented here. It is possible that the natural groundwater temperature may provide the limiting factor for a GWHP system rather than its flux, especially in northern parts of the country. Moreover, the geochemical composition of groundwater may limit the use of heat pumps in the coastal areas of Finland.

More research is needed to determine the site-specific factors limiting GWHP systems, especially in northern Finland, and also in the diverse geographical, geological and geochemical regions in southern Finland. The limiting factors may include the sustainable yield of the aquifer, groundwater temperature and chemical composition. Further investigation is also needed to measure the influence of the urban heat island effect 
on groundwater energy utilisation in the northern region. Careful thermogeological and environmental research is needed when planning individual GWHP systems. Hence, the information presented in this paper is indicative, and should not be used when planning heating and/or cooling systems for a single property.

\section{Competing interests}

The authors declare that they have no competing interests.

\section{Authors' contributions}

TA is the corresponding author, who planned the research, selected the co-authors, performed groundwater energy calculations for the groundwater energy database and wrote most part of the text. LE measured the design power by performing an IDA-ICE 4.1 simulation, prepared Table 3 and provided instructions for the heat pump equations in the methods section. JH performed ArcGis-related work and prepared Figure 4. KKN wrote a part of the Thermogeological environment in Finland' section and participated in the design of this study. She also supervised the planning of the research. All authors read and approved the final manuscript.

\section{Acknowledgements}

We thank the following persons for their support and advice: Juha Jokisalo, D.Sc., Professor Veli-Pekka Salonen, Dr. Martin Preene, Mikko Hynninen, M.Sc. Tech., Petri Siiro, M.Sc., Esko Nylander, M.Sc., Janne Mäkinen, M.Sc. and Dr. Roy Siddall for language revision. Special thanks to colleagues in the Turku office of Golder Associates. This research was funded by Golder Associates Oy, the foundation Maa-ja vesitekniikan tuki ry and the K.H. Renlund Foundation.

\section{Author details}

${ }^{1}$ Golder Associates Oy, Apilakatu 13B, Turku FI-20540, Finland. ²Department of Energy Technology, Aalto University, Sähkömiehentie 4, Aalto Fl-00076, Finland. ${ }^{3}$ Golder Associates Oy, Ruosilankuja 3E, Helsinki Fl-00390, Finland.

${ }^{4}$ Department of Geosciences and Geography, University of Helsinki, Gustaf Hällströmin katu 2a, Helsinki Fl-00014, Finland.

Received: 7 February 2014 Accepted: 3 June 2014

Published online: 26 June 2014

References

Allen A, Milenic D (2003) Low enthalpy geothermal energy resources from groundwater in fluvioglacial gravels of buried valleys. Appl Energ 74:9-19, doi:10.1016/s0306-2619(02)00126-5

Allen A, Milenic D, Sikora P (2003) Shallow gravel aquifers and the urban 'heat island' effect: a source of low enthalpy geothermal energy. Geothermics 32:569-578, doi:10.1016/s0375-6505(03)00063-4

Alley WM, Leake SA (2004) The journey from safe yield to sustainability. Ground Water 42:12-16

Banks D (2010) An introduction to thermogeology: ground source heating and cooling. Blackwell, Oxford

Bayer P, Saner D, Bolay S, Rybach L, Blum P (2011) Greenhouse gas emission savings of ground source heat pump systems in Europe: a review. Renew Sust Energ Rev 16:1256-1267, doi:10.1016/j.rser.2011.09.027

Bonte M, Stuyfzand P, Hulsmann A, van Beelen P (2011) Underground thermal energy storage: environmental risks and policy developments in the Netherlands and European Union. Ecol Soc 16(1):22

Brielmann H, Griebler C, Schmidt SI, Michel R, Lueders T (2009) Effects on thermal energy discharge on shallow groundwater ecosystems. FEMS Microbiol Ecol 68:273-286, doi:10.1111/j.1574-6941.2009.00674.x

Britschgi R, Antikainen M, Ekholm-Peltonen M, Hyvärinen V, Nylander E, Siiro P, Suomela T (2009) Pohjavesialueiden kartoitus ja luokitus. Ympäristöopas 2009. Finnish Environment Institute, Helsinki

Eggen G, Vangsnes G (2005) Heat Pump for district cooling and heating at Oslo airport, Gardemoen. In: proceedings of the 8th IEA Heat Pump Conference, USA May 30 - June 2 2005. HPP Publications, Sweden

EHPA (2009) European heat pump statistic - Outlook 2009. European Heat Pump Association, Brussels, Belgium

Environmental Protection Act 86 (2000) Finland. Government of Finland, Finland.

Ferguson G, Woodbury AD (2004) Subsurface heat flow in an urban environment. J Geophys Res 109:B02402, doi:10.1029/2003JB002715,2004

Fetter CW (1994) Applied Hydrogeology, 3rd edn. Prentice-Hall Inc., Upper Saddle River

Haehlein S, Bayer P, Blum P (2010) International legal status of the use of shallow geothermal energy. Renew Sust Energ Rev 14:2611-2625, doi:10.1016/j.rser.2010.07.069

Heap RD (1979) Heat Pumps. E. \& F.N. Spon Ltd, London

Holopainen R, Vares S, Ritola J, Pulakka S (2010) Maalämmön ja viilennyksen hyödyntäminen asuinkerrostalon lämmityksessä ja jäähdytyksessä. VIT - Research notes 2546, Espoo Finland, p 56

lihola H, Laitinen T (1984) An Energy-Efficient Utilization of Groundwater II. Vesi-Hydro Consulting Engineers. The Finnish Ministry of Trade and Industry, Department of Energy

lihola H, Laitinen T (1984) An Energy-Efficient Utilization of Groundwater II. Vesi-Hydro Consulting Engineers. The Finnish Ministry of Trade and Industry, Department of Energy, Helsinki, Finland

Kalamees T, Jylhä K, Tietäväinen H, Jokisalo J, llomets S, Hyvönen R, Saku S (2012) Development of weighting factors for climate variables for selecting the energy reference year according to the EN ISO 15927-4 standard. Energ Build 47(2012):53-60, doi:10.1016/j.enbuild.2011.11.031

Kalf RP, Woolley DR (2005) Application and methodology of determining sustainable yield in groundwater systems. Hydrogeol J 13:295-312, doi:10.1007/s10040-004-0401-x

Kerl M, Runge N, Tauchmann H, Goldscheider N (2012) Hydrogeologisches Konzeptmodell von München: Grundlage für die thermische Grundwassernutzung. Grundwasser 17(3):127-135, doi:10.1007/s00767-012-0199-8 
Korkka-Niemi K (2001) Cumulative geological, regional and site-specific factors affecting groundwater quality in domestic wells in Finland. Monogr Boreal Environ Res 20:102

Lahermo P, IImasti M, Juntunen R, Taka M (1990) The hydrogeochemical mapping of Finnish aquifers. Geochemical Atlas of Finland, part 1. Geological Survey of Finland, Espoo, p 66

Lindblad-Påsse A (1986) Järnutfällingsproblemer in grundvattenvärmesystem. Byggforskningrådet Rapport 109:1986

Lund J, Sanner B, Rybach L, Curtis R, Hellström G (2004) Geothermal (Ground Source) heat pumps a world overview. BHC Bulletin, OR, USA

Lunkka JP, Johansson P, Saarnisto M, Sallasmaa O (2004) Glaciation in Finland. In: Ehlers J, Gibbard PL (eds) Quaternary glaciations - extent and chronology. Elsevier, Amsterdam, pp 93-100

Mälkki E, Soveri J (1986) Pohjavesi. In: Mustonen S (ed) Sovellettu hydrologia. Vesiyhdistys ry. Mäntän kirjapaino, Mänttä

Ministry of Employment and the Economy (2008) Long term Climate and Energy Strategy. Government Report to Parliament 6, Helsinki

Ministry of Employment and the Economy (2010) Finland's national action plan for promoting energy from renewable sources pursuant to Directive 2009/28/EC. Ministry of Employment and the Economy, Energy Department, Helsinki

Ministry of Employment and the Economy (2011) Nuclear Energy in Finland. Ministry of Employment and the Economy, Helsinki

National Building Code of Finland (2005) G Housing planning and building. G1 Housing design. Finnish Environment Institute, Helsinki

National building code of Finland (2010) C Insulation. C3 Thermal insulation in buildings. Finnish Environment Institute, Helsinki

National Building Code of Finland (2012) D Hepac and environment. D3 energy management in buildings. Finnish Environment Institute, Helsinki

Official Statistics of Finland (2014) Building and dwelling production [e-publication]. ISSN=1798-9590. January 2014 Appendix table 2. Building permits monthly, 1000 m3. Helsinki: Statistics Finland [referred: 28.3.2014]. Access method: http://www.stat.fi/til/ras/2014/01/ras_2014_01_2014-03-26_tau_002_en.html

Oikari H (1981) Pohjaveden lämpötila Etelä- ja Keski-Suomessa vuosina 1975-1978. Vesihallituksen lähde- ja pohjavesiputkihavaintoihin perustuva selvitys, Pro gradu-tutkielma. Maantieteen Laitos, Luonnonmaantiede, Helsingin Yliopisto, Helsinki, p 65

Persson P (2007) Analyses of ground heating systems at Arlanda Airport. Optimization regarding the planned Aquifer Storage. Thesis for Master Science. Lund Institute of Technology, Department of Technical Geology, Lund, Sweden

Punkari M (1982) Glacial morphology and dynamics in the eastern part of the Baltic shield interpreted using Landsat imagery. Photogrammatic J Finl 9:77-93

Rosen B, Gabrielsson A, Fallsvik J, Hellström G, Nilsson G (2001) System för värme och kyla ur mark - En nulägesbeskrivning. Varia 511. Statens Geotekniska Institut, Lindköping, Sweden

Saarnisto M, Salonen VP (1995) Glacial history of Finland. In: Ehlers J, Kozarski S, Gibbard PL (eds) Glacial depos in North-East Europe. A-A Balkama, Rotterdam, pp 3-10

Salonen VP, Artimo A, Heikkinen P, Korkka-Niemi K, Pietilä S, Nuutilainen O, Pulkkinen K (2001) Hituran kaivoksen rikastushiekka-alueen jätevesivaikutuksen torjunta Töllinperän pohjavesialueella. In: Salonen VP, Korkka-Niemi K (eds) Kirjoituksia pohjavedestä. Department of Geology, University of Turku, Turku, pp 251-264

Salonen VP, Korkka-Niemi K, Moreau J, Rautio A (2014) Kaivokset ja vesi-esimerkkinä Hannukaisen hanke. Geologi 66(2014):8-19

Saner D, Juraske R, Kübert M, Blum P, Helweg S, Bayer P (2010) Is it only $\mathrm{CO}_{2}$ that matters? A life cycle perspective on shallow geothermal system. Renew Sust Energ Rev 14:1798-1813, doi:10.1016/j.rser.2010.04.002

Sanner B (2001) Shallow Geothermal Energy. GHC Bulletin, OR, USA

Sophocleus M, Devlin JF (2004) Discussion on the paper "The water budget myth revisited: why hydrogeologists model" by John D. Bredehoeft. Ground Water 42:618

Standart SFS-EN-15316-4-2 (2009) Heating systems in buildings. Method for calculation of system energy requirements and system efficiencies. Part 4-2. Space heating generation systems, heat pump systems. Finnish Standards Association, Helsinki

Statistical Finland (2013). http://www.stat.fi/tup/kunnat/kuntatiedot/398.html. Accessed 5 Dec 2013

Statistics Finland (2012) Energy statistics 2012. Official statistics of Finland, Statistics Finland, Helsinki

Statistics Netherlands (2012) Renewable energy in Netherlands 2010. Statistic Netherlands, The Hague

The Corine 2006 Database (2006). http://wwwd3.ymparisto.fi/d3/Static_rs/spesific/corinelandcover.html. Accessed 29 Dec 2011

The Hertta Database (2012). http://wwwp2.ymparisto.fi/scripts/hearts/welcome.asp. Accessed 29 Dec 2011 and $23 \mathrm{Feb} 2012$

Warren M (1994) Groundwater heat pump project - Junction City High School. ACR Engineering Inc. Report. GHC Bulletin, Oregon

Water Act (2011) Water Act 587/2011. Government of Finland, Finland

Yaws C (1998) Chemical properties handbook: physical thermodynamic, environmental, transport, safety and health related properties for organic and inorganic chemicals. McGraw-Hill, USA

Zhou Y (2009) A critical review of groundwater budget myth, safe and sustainability. J Hydrol 370:207-213, doi:10.1016/j.hydrol.2009.03.009

Zhu K, Blum P, Ferguson G, Balke KD, Bayer P (2010) The geothermal potential of urban heat islands. Environ Res Lett 5:044002, doi:10.1088/1748-9326/5/4/044002

doi:10.1186/s40517-014-0009-x

Cite this article as: Arola et al: Mapping the low enthalpy geothermal potential of shallow Quaternary aquifers in Finland. Geothermal Energy 2014 2:9. 